\title{
О. В. КРиворучко
}

Національний фармацевтичний університет

\section{ФЕНОЛЬНІ СПОЛУКИ ДЕРЕНУ СПРАВЖНЬОГО І ДЕРЕНУ ЛІКАРСЬКОГО}

Актуальність. Дерен справжній (Cornus mas) - цінна плодова, лікарська і декоративна рослина з родини деренові (Cornaceae), розповсюджена у природній флорі України і яка широко культивується. Дерен лікарський (Cornus officinalis) в Україні лише культивується як декоративна рослина. Раніше ми досліджували кислотний, терпеновий і мінеральний склад деренів, але склад фенольних сполук ще вивчений недостатньо.

Метою роботи було вивчення складу і вмісту фенольних сполук у листі і квітках дерену справжнього і дерену лікарського.

Матеріали та методи. Визначення фенольних сполук у листі і квітках дерену справжнього та у квітках дерену лікарського проводили методом BEPX на хроматографі фірми Agilent Technologies.

Результати та їх обговорення. Вміст флавоноїдів у листі дерену справжнього становить 847,6 мг/100 г, у квітках - 1704,9 мг/100 г; у квітках дерену лікарського - 1448,9 мг/100 г (у перерахунку на рутин). Вміст кислот у квітках дерену справжнього становить 41,5 мг/100 г, у квітках дерену лікарського - 124,9 мг/100 г (у перерахунку на кислоту хлорогенову). У листі дерену справжнього ідентифіковано рутин, у квітках дерену справжнього і дерену лікарського - кислоти хлорогенову і елагову, рутин, кемпферол-3-0-глюкозид і кверцетин. У всіх досліджуваних зразках переважає флавоноїд рутин.

Висновки. Методом ВЕРХ у листі і квітках дерену справжнього та у квітках дерену лікарського визначено склад і вміст фенольних сполук. Результати дослідження листя дерену справжнього використані при стандартизації сировини.

Ключові слова: дерен справжній (Cornus таs); дерен лікарський (Cornus officinalis); фенольні сполуки

\section{O. V. Krivoruchko}

\section{Phenolic compounds of Cornus mas and Cornus officinalis}

Topicality. Cornus mas is a valuable fruit, medicinal and ornamental plant from the family Cornaceae, which is widely distributed in the natural flora in Ukraine and it is widely cultivated. Cornus officinalis is only cultivated in Ukraine as an ornamental plant. Previously, we have studied the acid, terpenic and mineral composition of dogwoods, but the composition of the phenolic compounds is still studied insufficiently.

Aim. To study the composition and the content of Cornus mas and Cornus officinalis leaves and flowers phenolic compounds .

Materials and methods. The determination of phenolic compounds in leaves and flowers of Cornus mas and in flowers of Cornus officinalis was carried out by the HPLC method on a chromatograph Agilent Technologies.

Results and discussion. The content of flavonoids in leaves of Cornus mas is $847.6 \mathrm{mg} / 100 \mathrm{~g}$, in flowers $-1704.9 \mathrm{mg} / 100 \mathrm{~g}$; in flowers of Cornus officinalis - $1448.9 \mathrm{mg} / 100 \mathrm{~g}$ (in terms of rutin). The content of acids in flowers of Cornus mas is $41.5 \mathrm{mg} / 100 \mathrm{~g}$, in flowers of Cornus officinalis - $124.9 \mathrm{mg} / 100 \mathrm{~g}$ (in terms of chlorogenic acid). In leaves of Cornus mas rutin was identified, in flowers of Cornus mas and Cornus officinalis - chlorogenic and ellagic acids, rutin, kaempferol3-0-glucoside and quercetin. The flavonoid rutin predominates in the all studied samples.

Conclusions. Using the HPLC method in leaves and flowers of Cornus mas and in the flowers of Cornus officinalis the composition and the content of phenolic compounds were determined. Results of the study of leaves of Cornus mas were used for the standardization of raw materials.

Key words: Cornus mas; Cornus officinalis; phenolic compounds

\section{Е. В. Криворучко}

\section{Фенольные соединения кизила мужского и кизила лекарственного}

Актуальность. Кизил мужской (Cornus mas) - ценное плодовое, лекарственное и декоративное растение семейства кизиловые (Cornaceae), распространенное в естественной флоре Украины и широко культивируется. Кизил лекарственный (Cornus officinalis) в Украине только культивируется как декоративное растение. Ранее мы исследовали кислотный, терпеновый и минеральный состав кизилов, а состав фенольних соединений еще изучен недостаточно.

Целью работы было изучение состава и содержания фенольных соединений в листьях и цветках дерна настоящего и дерна лекарственного.

Материалы и методы. Определение фенольных соединений в листьях и цветках кизила мужского и цветках кизила лекарственного проводили методом ВЭЖХ на хроматографе фирмы Agilent Technologies.

Результаты и их обсуждение. Содержание флавоноидов в листьях кизила мужского составляет 847,6 мг/100 г, в цветках - 1704,9 мг /100 г, в цветках кизила лекарственного - 1448,9 мг/100 г (в пересчете на рутин). Содержание кислот в цветках кизила мужского составляет 41,5 мг/100 г, в цветках кизила лекарственного - 124,9 мг/100 г (в пересчете на кислоту хлорогеновую). В листьев кизила мужского идентифицирован рутин, в цветках кизила мужского и кизила лекарственного - кислоты хлорогеновая и эллаговая, рутин, кемпферол-3-О-глюкозид и кверцетин. Во всех исследуемых образцах преобладает флавоноид рутин.

Выводы. Методом ВЭЖХ в листьях и цветках кизила мужского и цветках кизила лекарственного определены состав и содержание фенольных соединений. Результаты исследования листьев кизила мужского использованы при стандартизации сырья.

Ключевые слова: кизил мужской (Cornus таs); кизил лекарственный (Cornus officinalis); фенольные соединения 


\section{ВСТУП}

Рід дерен або кизил (Cornus L.) з родини деренові (Cornaceae (Dumort) Dumort) об'єднує від одного до дев'яти підродів, до яких належать від 30 до 60 видів дерев і чагарників. У Дендрофлорі України описано 18 видів дерену, з яких тільки дерен справжній (Cornus mas L.) розповсюджений у природній флорі. Дерен справжній дуже близький морфологічно з дереном лікарським (Cornus officinalis Siebold et Zucc.) і дереном американським (Cornus sessilis Torr.), але ці види мають роз'єднаний ареал. У Євразії росте 3 види дерену: на заході материка - Cornus mas, на південному сході (в центральних районах Китаю) - Cornus chinensis, в Японії (рідше в Китаї і Kopeï) - Cornus officinalis. В Європі і Північній Америці більшість видів дерену традиційно використовують як декоративні рослини і тільки Cornus mas - як плодову. В Україні у дикому вигляді дерен справжній поширений переважно у південно-західній частині Правобережжя, у Карпатах, Закарпатті, Криму в підліску дубових і грабових лісів, чагарниках, по узліссях і схилах, по берегах річок, часом утворює суцільні зарості; практично повсюдно культивується. Дерен лікарський в Україні культивується в ботанічних садах і парках [1-3].

Основними діючими речовинами дерену справжнього і дерену лікарського $є$ фенольні сполуки, іридоїди і тритерпеноїди. Плоди досліджуваних деренів мають антиоксидантну, антимікробну, антирадикальну, гіпоглікемічну, протизапальну, гепатопротекторну, антиатеросклеротичну, в'яжучу, сечогінну, тонізуючу та інші види дій [1-4]. Раніше ми вивчали кислотний, ефіроолійний і мінеральний склад дерену справжнього і дерену лікарського $[1,5,6]$.

Метою цієї роботи було вивчення складу і вмісту фенольних сполук у листі та квітках дерену справжнього і дерену лікарського.

\section{МАТЕРІАЛИ ТА МЕТОДИ}

Для проведення дослідження квітки дерену справжнього і дерену лікарського заготовляли у квітні, листя - у травні 2014 року в ботанічному саду Харківського національного університету ім. В. Н. Каразіна.

Визначення складу і вмісту фенольних сполук у сировині проводили методом високоефективної рідинної хроматографії (BEPX) на хроматографі фірми Agilent Technologies за методикою, наведеною в [7]. Ідентифікували фенольні сполуки у листі та квітках дерену справжнього і дерену лікарського за часом утримування стандартів та спектральними характеристиками.

Хроматограма фенольних сполук квіток дерену лікарського наведена на рисунку, результати визначення вмісту фенольних сполук у досліджуваній сировині - в таблиці.

\section{РЕЗУЛЬТАТИ ТА ЇХ ОБГОВОРЕННЯ}

У листі дерену справжнього виявлено 4 фенольні сполуки, з яких ідентифіковано лише флавоноїд рутин. У квітках дерену справжнього і дерену лікарського ідентифіковано 5 фенольних сполук: кислоти хлорогенову і елагову та флавоноли рутин, кемпферол-3-0-глюкозид і кверцетин. У квітках дерену лікарського також виявлено похідне кислоти кофейної і глікозид кверцетину. В усіх досліджуваних зразках переважає флавоноїд рутин, причому у квітках дерену справжнього його міститься найбільше - 1582,5 мг/100 г (у перерахунку на рутин).

Вміст кислот у квітках дерену справжнього становить 41,5 мг/100 г, у квітках дерену лікарського 124,9 мг/100 г (у перерахунку на кислоту хлорогенову). Вміст ідентифікованих флавоноїдів у листі дерену справжнього становить 847,6 мг/100 г, у квітках - 1704,9 мг/100 г; у квітках дерену лікарського -

DAD1 C, Sig=350,32 Ref=off (HAR-2010IPHENOL09.D)

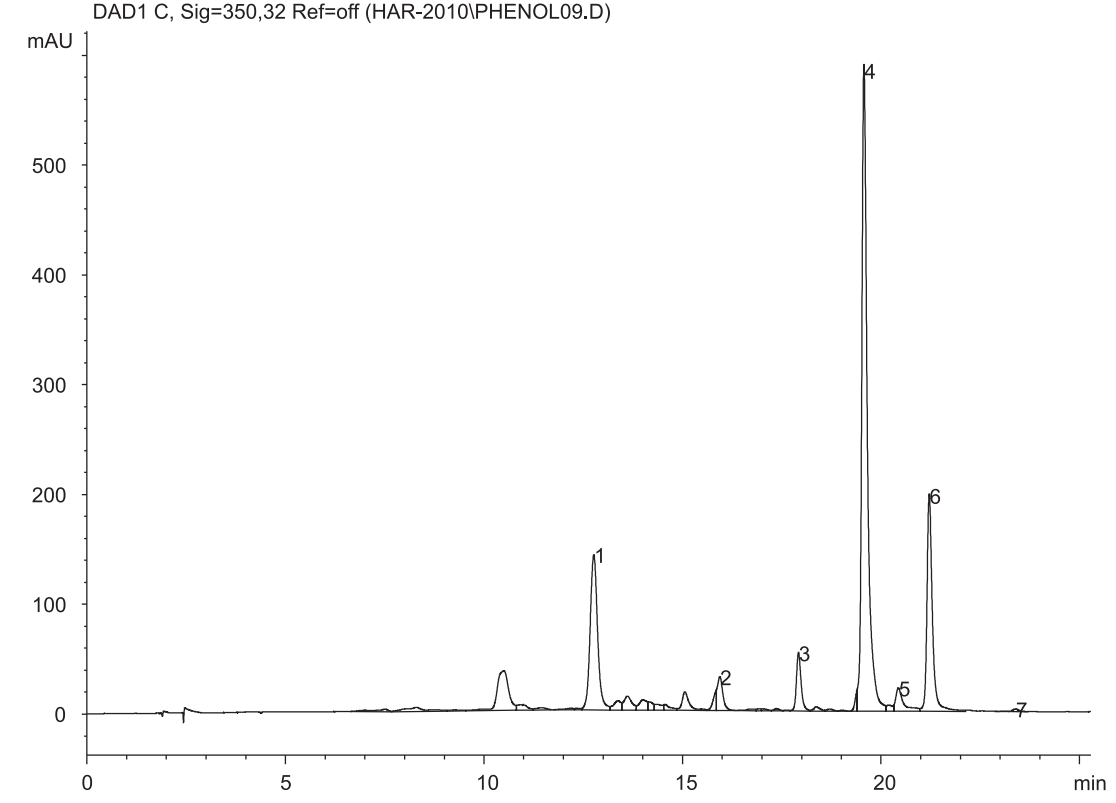

Рис. Хроматограма фенольних сполук квіток дерену лікарського (1 - кислота хлорогенова; 2 - похідне кислоти кофейної; 3 - глікозид кверцетину; 4 - рутин; 5 - кислота елагова; 6 - кемпферол-3-0-глюкозид; 7 - кверцетин) 
ВМІСТ ФЕНОЛЬНИХ СПОЛУК У ЛИСТІ І КВІТКАХ ДЕРЕНУ СПРАВЖНЬОГО І ДЕРЕНУ ЛІКАРСЬКОГО

\begin{tabular}{|c|c|c|c|c|}
\hline \multirow[b]{2}{*}{ Речовина } & \multirow[b]{2}{*}{ Час утримання, хв } & \multicolumn{3}{|c|}{ Вміст у сировині, мг/100 г } \\
\hline & & $\begin{array}{l}\text { листя дерену } \\
\text { справжнього }\end{array}$ & $\begin{array}{c}\text { квітки дерену } \\
\text { справжнього }\end{array}$ & $\begin{array}{c}\text { квітки дерену } \\
\text { лікарського }\end{array}$ \\
\hline Похідне кислоти кофейної & 15,94 & H/B & - & 21,1 \\
\hline Глікозид кверцетину & 18,09 & - & - & 78,0 \\
\hline Неідентифікована & 20,1 & 121,1 & - & - \\
\hline Кислота елагова & 20,44 & - & 10,7 & 7,7 \\
\hline Неідентифікована & 21,69 & 140,2 & - & - \\
\hline Кемпферол-3-0-глюкозид & 21,75 & - & 105,2 & 334,2 \\
\hline
\end{tabular}

Примітка: * - не визначали.

1448,9 мг /100 г (у перерахунку на рутин). Тому стандартизувати листя дерену справжнього ми пропонуємо за вмістом у них флавоноїдів (у перерахунку на рутин).

\section{ВИСНОВКИ}

1. Методом ВЕРХ на хроматографі фірми Agilent Technologies у листі і квітках дерену справжнього і у квітках дерену лікарського визначено склад і вміст фенольних сполук.

2. У листі дерену справжнього ідентифіковано рутин, у квітках дерену справжнього і дерену лі- карського - кислоти хлорогенову і елагову, рутин, кемпферол-3-0-глюкозид і кверцетин. У квітках дерену лікарського також виявлено похідне кислоти кофейної і глікозид кверцетину. В усіх досліджуваних зразках переважає флавоноїд рутин, причому у квітках дерену справжнього його міститься найбільше - 1582,5 мг/100 г (у перерахунку на рутин).

3. Результати дослідження листя дерену справжнього використані при стандартизації сировини.

Конфлікт інтересів: відсутній.

\section{ПЕРЕЛІК ВИКОРИСТАНИХ ДЖЕРЕЛ ІНФОРМАЦІЇ}

1. Криворучко, О. В. Фармакогностичне дослідження представників родин Розові та Деренові як джерел одержання лікарських засобів автореф. дис. ... доктора фарм. наук : 15.00 .02 / О. В. Криворучко ; Нац. фармац. ун-т. - Х., 2016. - 40 с.

2. Cornus mas L. (cornelian cherry), an important European and Asian traditional food and medicine : Ethnomedicine, phytochemistry and pharmacology for its commercial utilization in drug industry / B. Dinda, A. M. Kyriakopoulos, S. Dinda et al. // J. Ethnopharmacol. - 2016. - Vol. 193. P. 670-690. doi: 10.1016/j.jep.2016.09.042

3. The crude extract of Corni fructus induces apoptotic cell death through reactive oxygen species-modulated pathways in U-2 OS human osteosarcoma cells / C. L. Liao, S. C. Hsu, C. C. Yu et al. // Environ. Toxicol. - 2012. - Vol. 29, Issue 9. - P. 1020-1031. doi: 10.1002/tox.21832

4. Biochemical and histopathological study of the anti-hyperglycemic and anti-hyperlipidemic effects of Cornelian cherry (Cornus mas L.) in alloxan-induced diabetic rats / S. Asgary, M. Rafieian-Kopaei, F. Shamsi etal. // J. Complement Integr. Med. - 2014. - Vol. 11, Issue 2. doi: 10.1515/jcim-2013-0022

5. Krivoruchko, E. V. Constituent composition of essential oil from Cornus mas flowers / E. V. Krivoruchko, V. A. Samoilova, V. N. Kovalev // Chemistry of Natural Compounds. - 2011. - Vol. 47, Issue 4. - P. 646-647. doi: 10.1007/s10600-011-0020-4

6. Krivoruchko, E. V. Carboxylic Acids from Cornus mas / E. V. Krivoruchko // Chemistry of Natural Compounds. - 2014. - Vol. 50, Issue 1. P. 112-113. doi: 10.1007/s10600-014-0879-y

7. Самойлова, В. А. Фенольні сполуки листя аронії / В. А. Самойлова, В. М. Ковальов, О. В. Товчига // Зб. наук. праць співробіт. НМАПО імені П. Л. Шупика. - К., 2014. - Вип. 23 (4). - С. 380-385.

\section{REFERENCES}

1. Kryvoruchko, O. V. (2016). Farmakohnostychne doslidzhennia predstavnykiv rodyn Rozovi ta Derenovi yak dzherel oderzhannia likarskykh zasobiv. Kharkiv, NUPh, 40.

2. Dinda, B., Kyriakopoulos, A. M., Dinda, S., Zoumpourlis, V., Thomaidis, N. S., Velegraki, A., Dinda, M. (2016). Cornus mas L. (cornelian cherry), an important European and Asian traditional food and medicine: Ethnomedicine, phytochemistry and pharmacology for its commercial utilization in drug industry. Journal of Ethnopharmacology, 193, 670-690. doi: 10.1016/j.jep.2016.09.042

3. Liao, C.-L., Hsu, S.-C., Yu, C.-C., Yang, J.-S., Tang, N.-Y., Wood, W. G., Chung, J.-G. (2012). The crude extract of Corni Fructus induces apoptotic cell death through reactive oxygen species-modulated pathways in U-2 OS human osteosarcoma cells. Environmental Toxicology, 29 (9), $1020-1031$. doi: $10.1002 /$ tox. 21832

4. Asgary, S., Rafieian-Kopaei, M., Shamsi, F., Najafi, S., Sahebkar, A. (2014). Biochemical and histopathological study of the anti-hyperglycemic and anti-hyperlipidemic effects of cornelian cherry (Cornus mas L.) in alloxan-induced diabetic rats. Journal of Complementary and Integrative Medicine, 11 (2). doi: 10.1515/jcim-2013-0022

5. Krivoruchko, E. V., Samoilova, V. A., Kovalev, V. N. (2011). Constituent composition of essential oil from Cornus mas flowers. Chemistry of Natural Compounds, 47 (4), 646-647. doi: 10.1007/s10600-011-0020-4

6. Krivoruchko, E. V. (2014). Carboxylic Acids from Cornus mas. Chemistry of Natural Compounds, 50 (1), 112-113. doi: 10.1007/s10600-014-0879-y

7. Samoilova, V. A., Kovalov, V. N., Tovchiha, O. V. (2014) Zbirnyk naukovykh prats spivrobitnykiv NMAPO imeni P. L. Shupyka, 23 (4), $380-385$. 
Відомості про авторів:

Криворучко О. В., д-р фарм. наук, доцент кафедри фармакогнозії, Національний фармацевтичний університет.

E-mail: evphyto@gmail.com. ORCID: http://orcid.org/0000-0002-3106-0204.

Information about the authors:

Krivoruchko O. V., Doctor of Pharmacy, associate professor of the Department of Pharmacognosy, National University of Pharmacy.

E-mail: evphyto@gmail.com. ORCID: http://orcid.org/0000-0002-3106-0204.

Сведения об авторах:

Криворучко Е. В., д-р фарм. наук, доцент кафедры фармакогнозии, Национальный фармацевтический университет

E-mail: evphyto@gmail.com. ORCID: http://orcid.org/0000-0002-3106-0204.

Рекомендована д. фарм. н., професором С. М. Марчишин

Надійшла до редакції 14.11.2017 р 